DOI: 10.15356/2071-9388_02v09_2016_01

Markku Kulmala ${ }^{\text {* }}$, Hanna K. Lappalainen ${ }^{1,2}$, Tuukka Petäjä ${ }^{1}$,

Veli-Matti Kerminen ${ }^{1}$, Yrjö Viisanen ${ }^{2}$, GennadyMatvienko ${ }^{3}$, Vladimir Melnikov ${ }^{4}$, Alexander Baklanov ${ }^{5}$, Valery Bondur6, Nikolay Kasimov7, Sergej Zilitinkevich 2,1, 7, 8, 9

${ }^{1}$ Department of Physics, University of Helsinki, 00014 Helsinki, Finland

* Corresponding author, e-mail: markku.kulmala@helsinki.fi

2 Finnish Meteorological Institute, Research and Development, 00101 Helsinki, Finland

3 Institute of Atmospheric Optics, Russian Academy of Sciences, 634021 Tomsk, Russia

4 Institute of the Cryosphere of the Earth, Russian Academy of Sciences, 625026 Tyumen, Russia

${ }^{5}$ World Meteorological Organization, 1211 Genève, Switzerland

${ }^{6}$ AEROCOSMOS Research Institute for Aerospace Monitoring,

105064, Moscow, Russia

7 Lomonosov Moscow State University, Faculty of Geography, 119991 Moscow, Russia

8 Department of Radiophysics, Nizhny Novgorod State University, 603950 Nizhny Novgorod, Russia

${ }^{9}$ Institute of Geography, Russian Academy of Sciences,

119117 Moscow, Russia

\title{
PAN-EURASIAN EXPERIMENT (PEEX) PROGRAM: GRAND CHALLENGES IN THE ARCTIC-BOREAL CONTEXT
}

ABSTRACT. The role of arctic and boreal area is crucial in understanding rapidly changing global climate. The climate change itself has an enhanced effect in arctic and boreal areas. On the other hand, several feedback loops and mechanisms could either enhance or decelerate climate change. Besides these interlinks, the territory has enormous natural resources and the way they are utilised in future gives us a direction how to meet global grand challenges and regional impacts. Regionally, effective early warning systems and comprehensive monitoring will guide in reducing emissions in practise and save natural resources. Here we give insight into these issues, introduce the SMEAR (Station for Measuring Ecosystem-Atmosphere Relations) concept applicable to the PEEX network, and give a roadmap from deep understanding to practical solutions.

KEY WORDS: Grand Challenges, climate change, early warning systems, weather forecasting, arctic, boreal, research infrastructure, SMEAR concept, in situ observations, station network, WMO-GAW, data systems, GEOSS

\section{BACKGROUND}

Earth's system is facing several environmental challenges on a global scale, called "Grand Challenges". The growing population needs more fresh water, food and energy, which will affect our climate, air quality, ocean acidification, loss of biodiversity and shortages of fresh water and food supplies. Grand Challenges are the main factors controlling 
human well-being and security as well as the stabilities of future societies. Since the Grand Challenges are highly connected and interlinked, they cannot be solved separately. Therefore, a framework is needed in which a multidisciplinary scientific approach has the required critical mass and is strongly connected to fast-tracked policy making. The potential solutions are typically tightly coupled with each other (e.g. [Kulmala et al., 2015a]). To meet this requirement, a deep understanding based on new scientific knowledge is needed.

In order to avoid the collapse of the Earth system, one may estimate that the mankind has approximately a 40-year window of opportunity to find a common mind-set and practical solutions to answer the Grand Challenges. This estimate is based on the observed concentrations of $\mathrm{CO}_{2}$. This year the maximum monhtly mean observed in May at the WMO GAW station Mauna Loa was 404 ppm (NOAA 2015 data: ftp://aftp.cmdl.noaa. gov/products/trends/co2/co2_mm_mlo.txt), corresponding the global atmospheric $\mathrm{CO}_{2}$ concentration. If global $\mathrm{CO}_{2}$ emissions continue increasing at the same rate as they have done, within 40 years the $\mathrm{CO}_{2}$ concentration overpasses 500 ppm.

The atmosphere forms a major part of the environment to which life on Earth is sensitively responsive. The atmosphere closely interacts with the biosphere, hydrosphere, cryosphere, pedosphere and lithosphere as well as urban surfaces on time scales from seconds to millennia [Wanner et al., 2008]. Changes in one of these components are directly or indirectly communicated to the others via intricately-linked processes and feedbacks. In recent years, a lot of research has been motivated by the importance of atmospheric aerosols on the global radiation budget, cloud formation and human health. Concentrations of reactive gases, greenhouse gases (GHGs) and atmospheric aerosol particles are tightly connected with each other via physical, chemical and biological processes occurring in the atmosphere, biosphere and at their interface [Arneth et al. 2010, Stocker et al., 2013; Kulmala et al., 2014a; Unger et al., 2014]. Human and societal actions, such as emission policy, urbanization, forest management and land use change, as well as various natural feedback mechanisms involving the biosphere and atmosphere, have substantial impacts on the complicated couplings between atmospheric aerosols, trace gases, GHG, air quality and climate [Raes et al. 2010; Shindell et al. 2012; Stocker et al., 2013; Baklanov et al., 2015].

Northern regions $\left(>45^{\circ} \mathrm{N}\right)$ will undergo substantial changes during the next 40 years (e.g. [Smith 2010]]. The arctic boreal Northern Eurasian region, and especially the arctic coastal lines and Siberian region of the Russian territory, is extremely crucial for global climate (see also [Kulmala et al., 2015a]]. Permafrost thawing together with the Arctic sea ice changes will have multiple environmental (greenhouse gas emissions, air quality), economic (energy production, use of mineral, traffic and shipping and infrastructures) and societal (urbanization, cultural changes) consequences. Complex assessment of such consequences could be done using atlas systems. In Russia the National Atlas of Arctic is based on this conception [Kasimov et al., 2015].

Pan-Eurasian Experiment (PEEX) is an Arcticboreal multi-scale, multi-dimensional and multi-disciplinary program that started in 2012 and aims at resolving the major uncertainties in the Earth system science and global sustainability questions focusing on Northern Eurasian regions [Kulmala et al., 2011; Kulmala et al., 2015a; Lappalainen et al., 2014;]. PEEX is a bottom up initiative by European, Russian and Chinese research communities involving also scientists from other countries. The program is divided into four pillars: research approach, research infrastructure, impact on society and capacity building / knowledge transfer. The $1^{\text {st }}$ pillar is aimed to form holistic understanding of the dominating feedbacks and triggers of the land-atmosphere-aquatic systems and human activities relevant to the arctic-boreal region. The $2^{\text {nd }}$ pillar is 
designed to establish coherent, coordinated in-situ ground based observations systems [Hari et al., 2015] together with the remote sensing applications across Northern Eurasian region and a multiscale modelling platform. The $3^{\text {rd }}$ pillar is optimizing the impact of the research results for the use of Northern societies and connecting scientific assesment to fast-tracked policy making. The $4^{\text {th }}$ pillar is oriented on capacity building and to educate the next generation of scientists, engineers and technical staff to carry out and continue the approach of the first 3 pillars. In this paper we focus on the $2^{\text {nd }}$ pillar, the PEEX research infrastructure framework. We give insight on the SMEAR (Station for Measuring Ecosystem-Atmosphere Relations) concept, PEEX infrastructure framework and provide a roadmap from deep understanding to practical solutions of PEEX program [Lappalainen et al., 2014].

\section{PEEX NICHE IN A FRAME OF INTERNATIONAL RESEARCH INFRASTRUCTURE LANDSCAPE}

PEEX research is based on inter-disciplinary, multi-scale approach which mobilizes a diverse range of scientific and technological expertise, including chemistry, physics, biology, meteorology, engineering sciences, environmental sciences, economics and social sciences.The implementation of the research agenda is built on a novel research infrastructure structure and involves laboratory studies, ground, ship and airborne field studies, satellite remote-sensing as well as numerical modelling studies ranging from the molecular ab initio molecular level to the global-scale Earth system models. The backbone of the research infrastructures is a network of continuous, comprehensive flagship stations [Hari et al., 2015], obtained by establishing new stations and/or updating existing stations. The regional coverage of stations and the quality of metadata including open access are the key issues for success.

The PEEX program is completing several ongoing or newly launched initiatives, programs, actions by European Union Horizon 2020, Belmont Forum, IIASA, WMO GAW and SAON. It provides an integrative approach interms of the four-pillar program concept, with all the scales taken into account in the analysis and methods, including a joint analysis of Arctic -boreal geographical domain. The PEEX research agenda is aimed to find solutions to global challenges and answers to PEEX science questions related, for example, the changing Arctic-boreal environments in terms of the greening Arctic (see [Kulmala et al., 2015]).

Furthermore, the PEEX research infrastructure aims to fill in the observational gap of coordinated and coherent in situ observations in the Northern Eurasian region. This task contributes to the intensive development of research infrastructure and supporting actions taking place in Europe, US (incl. The National Ecological Observatory, NEON US; ARM Climate Research facility) and other parts of the world, as well as to the ongoing, largescale coordination of the world research data systems (The Global Earth Observation System of Systems, GEOSS; Global Atmosphere Watch GAW-WMO)

\section{SMEAR CONCEPT AS APPLIED TO PEEX OBSERVATION SYSTEM}

One of the first tasks of the PEEX infra pillar is to establish a process towards high-level Northern Eurasian Observation Networks. Particularly the Siberian region is currently lacking a coordinated and coherent groundbased atmosphere-ecosystem measurement network crucial for observing and predicting the effects of climate change in the Northern Pan-Eurasian region. The SMEAR concept provides a state-of-the-art foundation for establishing a PEEX observation system that integrates this system to the global GEOSS data system

\section{SMEAR concept essentials}

The SMEAR (Station for Measuring EcosystemAtmosphere Relations) concept has been 
developed by University of Helsinki, Division of Atmospheric Sciences together with Division of Forest Ecology starting from 1995 [Hari \& Kulmala 2005; Hari et al., 2005; Hari et al., 2009]. Today the SMEAR stations are facilitated with versatile measurement equipment and are carrying out continuous data flow. This enables to analyse the long-term trends in the aerosol, trace gas and GHG loadings over boreal forests and other surfaces as well as to test novel theories and instrumental techniques under different environmental conditions. The instrumentation of the flagship SMEAR station (SMEAR-II-Hyytiälä) covers over 1000 different measurements from standard weather station parameters to mass spectrometers and cloud radars. The basic idea is to measure the mass and energy transport between the atmosphere and surface, in order to understand processes, interactions and feedbacks. The core measurements of SMEAR stations cover meteorological parameters, such as the temperature, relative humidity, wind, precipitation and radiation, as well as atmospheric composition and biological activity (incl. aerosols, clouds, atmospheric chemistry, greenhouse gases, $\mathrm{CO}, \mathrm{O}_{3}, \mathrm{NO}_{x^{\prime}} \mathrm{SO}_{2}$, VOCs, $\mathrm{CH}_{4}, \mathrm{NH}_{3}, \mathrm{H}_{2} \mathrm{SO}_{4}, \mathrm{HONO}, \mathrm{HNO}_{3}$, ions, external radiation, radon, photosynthesis, soil profiles and chemistry). These measurements include both concentrations and fluxes.

In Finland, SMEAR-type measurements are currently conducted at six stations located in forests, peatlands and lakes (atmospherebiosphere interface), and in urban (urban surface) and marine/coastal environments. The core measurements in each station are the same, in addition to which specific measurements characteristic for different environments are carried out. Globally, the concept provides a unique basis to diversify the aerosol, trace gas and GHG measurements into different environments providing crucial information for global climate models and regional air quality models [Ghan et al., 2012; Zhang et al., 2012; Schutgens and Stier, 2014]. A fundamental part of the SMEAR measurement concept is to connect in situ measurements to satellite based information [Kulmala et al.,
2011]. In order to cover the whole globe and be able to establish a Global SMEAR network, new proxies based on satellite data need to be developed as well [Bondur, 2011, 2014].

\section{Technical elements of the SMEAR concept}

The SMEAR concept consists of elements like the technical description of the SMEAR station prototypes at different hierarchy levels, SMEAR data system and plan of a global SMEAR station network. These main elements of the SMEAR concept are applicable to developing the existing stations, building new stations at once or to be uprated gradually towards a flagship station. For example, in Russia we have already mapped 206 potential atmospheric or ecosystem stations that could be a part of the PEEX-Russia observation network [Alekseychik et al., 2016]. Furthermore, we have already selected stations which could provide a pilot approach together with most advanced station in Russia and be integrated towards SMEAR measurement concept (Fig. 1).

The SMEAR station prototype description includes determination of the measurement parameters together with the instrument setups. A prototype description describes the station facility requirements (electricity, computer power, net connections, data flows \& storage, towers, buildings, roads) and technical staff (man hours) requirements. A science plan can be tailored to each station in order to maximise the setup's scientific outcome and utilization of the measurements capacity of the whole network.

The SMEAR data description covers several aspects of data systems: data policy, data formats together with the description of a higher level data products, data delivery with a user interface, open data access and data quality assurance procedures (calibration laboratory, traceable calibrations). The SMEAR data products enhance scientific exchange also with user communities working on models, satellite retrievals and forecast systems. The near-real-time (NRT) data streams can be linked the European 


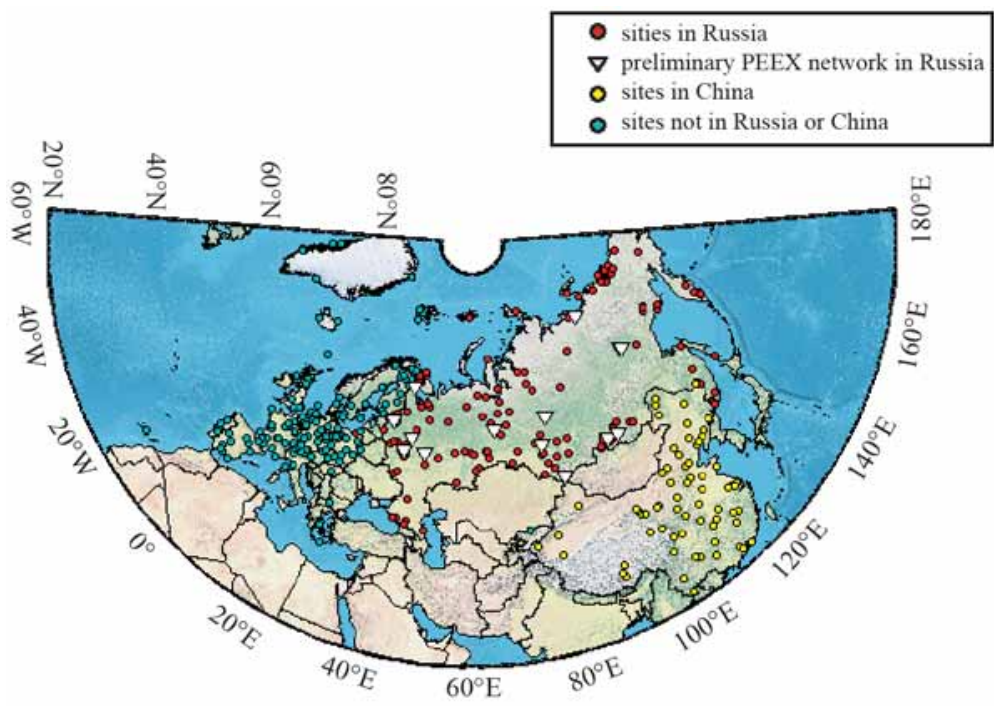

Fig. 1. Locations of permanent ground-based observation stations in the PEEX domain (Lappalainen et al. 2016, manuscript in preparation). The stations in Russia could provide a PEEX network pilot approach and be integrated to the SMEAR measurement concept.

Copernicus (former GMES) and WMO Global Atmosphere Watch (GAW) systems. The SMEAR data system uses automatic operation and remote control procedures which enable interoperability with the ICOS (carbon observations), ACTRIS (aerosols, trace gases, clouds) and ANAEE (experimental ecosystem measurements) stations. Optimal format and procedures for NRT data for each variable are defined including the initial and second level quality assurance (QA) for the incoming NRT data. The sustained SMEAR data streams for NRT reporting include station diagnosis and interoperability between local data center as well as data stream integration in other networks data centers.Dissemination of the data products can be connected to SMARTSMEAR web-interface [Junninen et al., 2009].

\section{Global SMEAR}

The Global SMEAR network plan introduces an optimal geographical coverage of a network, with a hierarchy structure of stations, investment plan, and how to find synergy with the existing research infrastructures and the connections with satellites and data systems. The global network will utilize existing knowledge of recommendations and guidelines for establishing a long-term, highly-standardized network system of the WMO-GAW (2009; 2014). GEOSS together with the European Union Environmental Infrastructures of ESFRI, the European Strategy Forum on Research Infrastructuresand Horizon 2020 RI-projects provide the framework for the harmonized data products development and calibration of network measurements with international standards. ESA's Climate Change Initiative (CCI) programme provides validated and improved satellite observations of atmospheric, land and ocean parameters.

\section{PEEX INFRASTRUCTURE FRAMEWORK}

The PEEX research infrastructure development is a back bone for performing the PEEX research agenda. It is important to understand that novel infrastructure and data are not only the basis for scientific breakthroughs but have also direct impacts on several other sectors of interest. A novel Rl is useful for different type of end-users, including climate and air quality policy makers at regional and global scales, regional operational services and people developing new observation techniques and innovations for global markets (Fig. 2). 


\section{IMPACT}

Research -Deeper understanding in process level \& upscaling

\section{Climate \&}

Air Quality

•polocy making

Ecosystem services

\section{PEEX \\ RI}

Monitoring -filling the gap

Observation

techniques -innovative -methods, instruments Real-time data products -modern - operational -services

\section{END-USER}

-land - atmosphere - ocean feedbacks -quantifying biogeochemical cycle - air quality - climate interactions - air quality - pollution - aerosol - clouds including weather -natural and anthropogenic hazards

- COP21 protocol process

-improved air quality standards - ecosystems -health effects

-clean water

-decomposition of wasters

- complete Earth Observation data -maintain state of art measurements -development of measuments -future monitoring strategies

-improved rainfall and severe weather predictions for risk control -in natural hazards, traffic control, agriculture, tourism.. -chemical weather prediction
-Research communities -European Environment Agency

-Roshydromet -geoengineering

-IPCC

-decision makers -intergovernmental organizations -local government -citizens

-ESA, EMEP -CLRTAP-EMEP -ROSHYDROMET -AEROCOSMOS -WMO-GAW -AERONET

•national weather services -instrument industry -SME -spin-off economical forecasting activities

Fig. 2. The potential impact sectors and end-user groups of the PEEX Research Infrastructure (RI). Similar type of impact and end-user approach was applied in a frame of developing ACTRIS infrastructure in Europe.

\section{PEEX Research Infrastructure (RI) contributing scientific breakthroughs in system understanding}

We need comprehensive data from the Pan-Eurasian region for not only answering the most urgent science questions but also solving the air quality dynamics of megacities like Moscow and other megacities [Kulmala et al. 2015b; Zilitinkevich et al., 2015]. The PEEX research agenda introduces largescale research questions and topics relevant to Arctic-boreal region [Kulmala et al., 2015a; Lappalainen et al., 2016]. The new understanding of feedbacks, atmospheric interactions of greenhouse gases, aerosols and trace gases and their connection to the biosphere and anthropogenic activities need to be implemented into large-scale climate models, regional models and atmospheric chemistry models. At the moment the existing observation networks do not deliver information with sufficient accuracy to understand feedback loops, interactions and processes in the land-atmosphericocean continuum. As a whole, connected measurements provide a potential for scientific breakthroughs.

Greenhouse gases like $\mathrm{CO}_{2}$ are relatively well-mixed worldwide, in strong contrast to, for example, aerosols that are highly spatially inhomogeneous depending on the development level of different regions. More data are needed to improve the process understanding and model quality. The PEEX RI aims to provide climate components needed for understanding how the intensity of anthropogenic actions, ecosystem biological activity and water cycle are inter-linked with the climate system. Trace gases and atmospheric aerosols are tightly connected with each other via physical, chemical, meteorological and biological 
processes occurring in the atmosphere and at the atmosphere - biosphere - water cycle interfaces. For example, the precipitation response and thus the hydrological sensitivity differ strongly for greenhouse gas forcing and aerosol forcing. Decreasing aerosol emissions in the future can lead to an even stronger increase in precipitation as can be expected from GHG forcing alone [Westervelt et al., 2015].

\section{PEEX RI contributing to Climate and Air Quality Policy at regional and global scale}

PEEX also aims to provide policy-relevant understanding of the Arctic-boreal environments as a whole to supervise and contribute to the United Nations Framework Convention on Climate Change, the Conference of the Parties (COP) and Subsidiary Body for Scientific and Technological Advice (SBSTA) approach and implementation.The EU Commission has proposed in January 2014 a greenhouse gas $(\mathrm{GHG})$ reduction target of $40 \%$ for 2030. The latest UN Climate Change Conference was held in Paris, in December 2015. In the global climate context, IPCC forum is one of the most import end-user and collaborators of PEEX approach.

Health effects due to air pollution and potential damage from climate change are among the most important environmental problems facing megacities like Moscow and Beijingor other urbanized territories [Baklanov et al., 2012, Kasimov et al., 2014, Guo 2014, Kulmala 2015b, Petäjä et al., 2015]. Quantification of contributions from different anthropogenic and natural sources to the trace gas and aerosol particle load is needed, along with improved source apportionment. Data from Northern Eurasian regions is urgently needed to be linked to the European databanks (incl. EMEP http://www.emep. int/, EBAS databases http://ebas.nilu. no/), in order to collect new information on regional $\mathrm{GHG}$, trace gas and aerosol loadings, estimates on hygroscopicity (related to dose of the population from the loadings) and composition (related to toxicity of the particles) and estimates of how much of the loading is due to the long range transport.

The social benefits are optimal when timely, high-quality and long-term observational data and modeling data are available to aid air quality decision-makers at every level from intergovernmental organizations to local government and then to citizens. World Health Organization (WHO) has estimated that in 20127 million premature deaths world-wide attributed to air pollution, which makes it the single largest cause of death in the world (WMO 2015).

Long-term information on trends is crucial for understanding the land-atmosphere interactions of urban environments and effectiveness of air quality policies. So far, the best results have been related to the verification of the feedback loops [Kulmala et al., 2004, 2013, 2014], Biogeochemical cycles and atmospheric new particle formation (e.g. [Mäkelä et al., 1997, Kulmala et al., 2013]). By quantifying processes, interactions and feedbacks related to the PEEX objectives. We will be able to identify, for example, the steps that are needed to reduce air pollution levels in megacities by a factor of 3-4, to determine how pollutant emissions in China are affecting arctic and boreal areas, and to find out how these effects will be changed due to future emission reductions in Russia and China.

Novel measurement data can also be used for a cost-benefit analysis relevant to different actions to improve air quality, fresh water and food supply, environmentally and economically sustainable use of natural resources including energy, and to prevent further climate change. Such activity would be linked to continuous and comprehensive research, atmospheric and emission modelling, and the process level understanding at regional scale. For example, the factors controlling the air quality in mega-cities need to be quantified and recognized, and the solutions need to be found in collaboration with the private sector, the local government and the national 
government levels [Zilitinkevich et al., 2015]. It is also important to investigate application of active remote sensing instruments, such as ceilometers and weather radars, to diagnose weather conditions leading to severe air pollution episodes.

\section{PEEX RI contribution to operational services at regional scale}

There will be large regional differences in warming due to the changing surface conditions and permanent changes in circulation or precipitation patterns (IPCC). Refer to European ACTRIS-I3-RI Roadmap regional monitoring of climate change is important to documenting to what extent the predicted climate change will actually occur and to take it into account in the development of weather forecast and climate models. National weather services need wellmeasured climatic components for testing improved physical parameterizations in weather forecast models predicting hazardous weather events. Weather services also need to evaluate cloud-aerosol and other air-pollutant schemes in forecast models. Near-real-time applications are also needed for chemical weather prediction to be delivered to policy makers at all levels and to the general public. To be able to respond to these requirements, the most climatic regions of Northern Eurasia should be represented by at least one PEEX core station for high resolution observations.

Current operational weather forecast models have maximal horizontal resolution of $1 \mathrm{~km}$ or so and cannot resolve microphysical processes; instead, these are to be parameterized in terms of bulk variables held in the mode, typically at about 1-km scale. Concrete formulations of major parameterization schemes cause much uncertainty in the forecasts, and are the area of active research. Improvement can only take place if we have a number of well-provided atmospheric observatories equipped with Doppler cloud radars and advanced lidars, providing continuous vertical profiles, aerosols, cloud particles and their phase (liquid or ice) across the atmosphere as addressed by the ACTRIS-13-Roadmap. Such stations, covering the climates of Northern Eurasia will, firstly, provide data for evaluating the performance of current weather forecasting models, and, secondly, suggest improved parameterization schemes to improve the forecast performance.

Similar to the European ENVRI (ACTRIS, ICOS, etc.) approach, the PEEX approach aims to harmonize the on-line, trace level gaseous air pollutant measurements, and yield reliable concentration fields and trends over Russia. This would help to quantify the relative contribution of anthropogenic sources and improve air pollution abatement strategies. Furthermore, this would support reliable monitoring of particulate and gaseous air pollutants at high time-resolution in a standardized way across the Northern Eurasia region and is of interest for the climate and air quality modeling community, and political entities and general public.

\section{New observation techniques and innovations having global markets}

New observation technologies will be an outcome applicable to different commercial sectors, such as bio-economy, Clean-tech and digitalization. New technologies can be implemented at locations in different climate regions and will enable local governments to base their policy on more accurate expectations of regional climate change, and local industry to develop appropriate products and technologies to counteract or adapt to local climate change. This is an important development, especially in light of the future climate change and its consequences. Climate monitoring will increasingly become vital for future societies. Many spin-off economical activities, based on improved rainfall and severe weather predictions, are to be expected; e.g. in natural hazards, in (air) traffic control, in agriculture and tourism. Development of new methods and instrumentation will also have important impacts on small and medium-sized enterprises (SMEs), innovation, market etc. 
The new emerging area of technical innovations is called a global change geoengineering or climate change engineering, also introduced by the PEEX $4^{\text {th }}$ pillar: the society impact [Lappalainen et al., 2014]. The term "climate engineering" covers a number of different technologies which aim to achieve large-scale technical intervention in the climate system, but which, at the same time, differ substantially with regard to the associated risks, effectiveness, side-effects and cost of deployment. The climate change engineering is designed to affect the Earth's radiation budget in two ways: altering the Earth's radiation budget without reducing greenhouse gas concentrations or reducing the greenhouse gas concentrations so that to change the Earth's radiation budget.

\section{FUTURE OUTLOOK AND ROADMAP}

The PEEX network is needed for ensuring the utilization of natural resources in an effective, yet sustainable way. The network would have a capacity to act as a backbone for Early Warning System and improved weather prediction. It would fill in the current observational gap in the Siberian region and bring the observation setup into international context with standardized or comparable procedures. The starting point on the way to sustainable solutions in Northern Eurasian region is to establish flagship stations for continuous and comprehensive observations as a part of the GLOBAL SMEAR network and the Global Atmosphere Watch Programme. The SMEAR flagship stations would cover a full suite of instruments and data systems for monitoring the material and energy flows in the land-atmosphere continuum, whereas some stations would have a targeted instrumentation for a specific topics and/or regions for providing spatial variance of the parameters.

As a summary we propose the following roadmap:

1. Establishment of a continuous, comprehensive measurements network (Global
SMEAR network) for global observations, including PEEX ground based in situ observations (supersites) completing the satellite remote sensing observations.

2. Establishment of open data flows and joint data analyses including: open access to observational data and metadata, modelling platforms, emission source analyses, and integration of all scale experimental and modelling results. Via novel data and modelling platforms, PEEX will make it possible to quantify airquality-climate interactions and feedbacks, particularly for megacities in Russia and China, and to analyse the biosphere-trace gas-aerosol-cloud interactions and feedbacks in the Northern Eurasian area, in order to determine past and present conditions and to predict future conditions of the continental planetary boundary layer, as well as boundarylayer climates, and development of arctic greening.

3. Performing economically effective structural changes and constructing reliable early warning systems, based on the data and holistic analysis sustainable solutions and decisions.

PEEX implements strategic tasks of the Sustainable Earth System Manifesto (Kulmala et al.) in the Northern Eurasian region. The latter addresses the urgent need for observations of critical environmental parameters worldwide, evoking a political consensus to overcome various geopolitical interests and prioritize the sustainable living conditions in different parts of the world, and providing sustainable technological solutions for the Grand Challenges aimed at efficient moderation of environmental changes. The PEEX agenda contributes to the Manifesto by providing conceptual design of the landatmosphere observation network for the Northern regions, in particular, for Russia. Furthermore, PEEX contributes to the global agenda by acting as a Future Earth Arcticboreal hub in frames of coordination of the Earth System research, and belongs to the key initiatives of GEOSS Cold Region activities. 
PEEX will actively seek for long-term funding in order to establish new SMEAR-concept stations and to make their continuous operation possible. All this should be based on national, bilateral, Nordic and allEuropean funding with matching funding concepts in Russia and China. Estimated building cost is approximately 15-20 million Euros per one flagship station. Such stations can be grown up from integrative blocks (1 million Euros per block). The annual operation costs are ca $10 \%$ of the investment costs.

\section{ACKNOWLEDGEMENTS}

We acknowledge support from "International Working Groups, Markku Kulmala" Grant by Finnish Cultural Foundation, Academy of Finland projects ICOS 271878, ICOS-Finland No. 281255, ICOS-ERIC No. 281250, No. 259537, 218094, 255576, 286685, 280700 and 259537 funded, Tekes- project Beautiful
Beijing, Nordforsk NCoE-CRAICC (no 26060) and Nordforsk CRAICC-PEEX-Amendment to contact 26060, the European Erasmus + CBHE project ECOIMPACT 561975-EPP-1-2015-1-FIEPPKA2-CBHE-JP (2015-2018); Academy of Finland project ABBA No. 280700 (2014-2017); Russian Ministry of Education and Science Mega-grant No. 11.G34.31.0048 (2011-2015); Russian Science Foundation projects No. 1517-20009 (2015-2018) and No. 15-17-30009 (2015-2018), geochemical foundations of PEEX were developed under support of the Russian Science Foundation project No. 14-27-00083 (2014-2016).

Furthermore, we thank Russian Ministry of Education and Science Grant № 14.583.21.0003, unique identifier of the project RFMEFI58314X0003 (ISR "AEROCOSMOS", 2014-2016); Russian Ministry of Education and Science Grant № 14.586.21.0004, unique identifier of the project RFMEFI58614X0004 (ISR "AEROCOSMOS", 2014-2016).

\section{REFERENCES}

1. ACTRIS-I3 Roadmap (2012) (EU-FP7-ACTRIS-I3), Internal Project Report For European Commission by H.K. Lappalainen (Univ. Helsinki / FMI), M. Kulmala (Univ. Helsinki), G. Pappalardo (CNR-IMAA) P. Laj (CNRS-LGGE), S. Sorvari, Univ. Helsinki / FMI)

2. Alekseychik, P., Lappalainen, H.K., Petäjä, T., Zaitseva, N., Arshinov, M., Shevchenko, V., Makshtas, A., Dubtsov, S., Mikhailov, E., Lapshina, E., Kirpotin, S., Kurbatova, Yuand Kulmala, M. (2016) PEEX potential ground station network: an overview. in press J. Geography Environment, Sustainability.

3. Arneth, A., Harrison, S.P., Tsigaridis, K., Menon, S., Bartlein, P.J., Feichter, H., Korhola, A., Kulmala, M., O'Donell, D., Schurgers, G., Sorvari, S., Vesala, T. and Zaehle, S. (2010) Terrestrial biogeochemical feedbacks in the climate system: from past to future. Nature Geoscience, 3, 525-532.

4. Bondur V.G. (2014). Modern Approaches to Processing Large Hyperspectral and Multispectral Aerospace Data Flows. Izvestiya, Atmospheric and Oceanic Physics. Vol. 50. No. 9. P. 840-852. DOI: 10.1134/S0001433814090060.

5. Bondur V.G. (2011) Satellite Monitoring of Wildfires during the Anomalous Heat Wave of 2010 in Russia // Izvestiya, Atmospheric and Oceanic Physics. Vol. 47. No. 9, P. 1039-1048.

6. Baklanov A.A., Bondur V.G., Klaić Z.B. and Zilitinkevich S.S. (2012) Integration of geospheres in Earth systems: Modern queries to environmental physics, modelling, monitoring and education // Geofizika. 2012. № 29 (2). P. 1-4. 
7. Baklanov, A., L.T. Molina and M. Gauss, (2015) Megacities, air quality and climate. Atmospheric Environment 126: 235-249.

8. GAW Report No. 207. Recommendations for a Composite Surface-Based Aerosol Network, Emmetten, Switzerland, 28-29 April 2009, 66 pp, November 2012

9. Ghan, S.J., Liu, X., Easter, R.C., Zaveri, R.,Rasch, P.J. and Yoon, J.-H. (2012) Toward a minimal representation of aerosols in climate models: Comparative decomposition of aerosol direct, semidirect, and indirect radiative forcing, J. Climate, 25, 6461-6476.

10. Guo, S., Hu, M., Zamora, ML., Peng, J., Shang, D., Zheng, J., Du, Z., Wu, Z., Shao, M., Zeng, L., Molina, MJ. And Zhang, R. (2014) Elucidating severe urban haze formation in China, Proc. Nat. Acad. Sci. USA, 111, 17373-17378.

11. Hari, P., Petäjä, T., Bäck, J., Kerminen, V-M., Lappalainen, H.K., Vihma, T., Laurila, T., Viisanen, Y., Vesala, T. and Kulmala, M. (2015) Conceptual design of a measurement network of the global changeAtmos. Chem. Phys. Discuss., 15, 21063-21093.

12. Hari, P. and Kulmala, M. (2005) Stations for Measuring Ecosystem - Atmosphere Relations (SMEAR II), Boreal Env. Res., 10, 315-322.

13. Hari, P., Andreae, M.O., Kabat, P., and Kulmala, M. (2009) A comprehensive network of measuring stations to monitor climate change, Boreal Env. Res., 14, 442-446.

14. Junninen, H., Lauri, A., Keronen P.I.R., Aalto, P., Hiltunen, V., P. and Kulmala, M. (2009) SmartSMEAR: on-line data exploration and visualization tool for SMEAR stations, BER 14, 447-457.

15. Kasimov, N.S. et al. (2014) Regions and Cities of Russia: the integrated assessment of ecological state, Moscow, 560 p.

16. Kasimov N.S., Kotlyakov V.M., Chilingarov A.N., Krasnikov D.M., Tikunov V.S. (2015) National Atlas of Arctic: structure and creation approaches. Ice and Snow, 1 (55), 4-14.

17. Kulmala, M., Suni, T., Lehtinen, K.E. J., Dal Maso, M., Boy, M., Reissell, A., Rannik, Ü., Aalto, P., Keronen, P., Hakola, H., Bäck, J., Hoffmann, T., Vesala, T., and Hari, P. (2004) A new feedback mechanism linking forests, aerosols, and climate, Atmos. Chem. Phys., 4, 557-562, doi:10.5194/acp-4-557-2004.

18. Kulmala M., Arola, A., Nieminen, T., Riuttanen, L., Sogacheva, L., G. de Leeuw G., Kerminen, V.-M. and Lehtinen, K.E.J. (2011) The first estimates of global nucleation mode aerosol concentrations based on satellite measurements, Atmos. Chem. Phys., 11, 10791-10801, doi:10.5194/acp-11-10791-2011.

19. Kulmala, M., Alekseychik, P., Paramonov, M., Laurila, T., Asmi, E., Arneth, A., Zilitinkevich, S., and Kerminen, V.-M. (2011) On measurements of aerosol particles and greenhouse gases in Siberia and future research needs, Boreal Env. Res., 16, 337-362.

20. Kulmala, M., Kontkanen, J., Junninen, J., Lehtipalo, K., Manninen, H., Nieminen, T., Petäjä, T., Sipilä, et al. (2013) Direct Observations of Atmospheric Aerosol Nucleation, 339 (6122), 943-946 DOI: 10.1126/science.1227385. 
21. Kulmala, M., Nieminen, T., Nikandrova, A., Lehtipalo, K., Manninen, H.E., Kajos, M.K. and Kerminen, V.-M. (2014a) CO $\mathrm{CO}_{2}$-induced terrestrial climate feedback mechanism: From carbon sink to aerosol source and back. Boreal Environment Research, 19 (suppl. B), 122-131.

22. Kulmala, M., Petäjä,T., M. Ehn, M., Thornton, J., Sipilä, M., Worsnop, D.R. and Kerminen, V.-M. (2014b) Chemistry of Atmospheric Nucleation: On the Recent Advances on Precursor Characterization and Atmospheric Cluster Composition in Connection with Atmospheric New Particle Formation, Annu. Rev. Phys. Chem., 65, 21-37.

23. Kulmala, M, Lappalainen, H.K., Petäjä, T., Kurten, T., Kerminen V.-M., Viisanen, Y., Hari, P., Sorvari, S., Bäck, J., Bondur, V., Kasimov, N., Kotlyakov, V., Matvienko, G., Baklanov, A. Guo, H.D., Ding A., Hansson H.-C. and Zilitinkevich, S. (2015) Introduction: The Pan-Eurasian Experiment (PEEX) - multi-disciplinary, multi- scale and multi-component research and capacity building initiative, Atmos. Chem. Phys., 15, 13085-13096.

24. Kulmala, M (2015) Atmospheric chemistry: China's choking cocktail, Nature, 526, 497499 (22 October 2015), doi:10.1038/526497a.

25. Lappalainen, H.K., Petäjä, T., Kujansuu, J., Kerminen, V-M., Shvidenko, A., Bäck, J., Vesala, T., Vihma, T., de Leeuw, G., Lauri, A., Ruuskanen,T., Lapshin V., Zaitseva, N., Glezer, O., Arshinov,M., Spracklen, D.V., Arnold, S.R., Juhola, S., Lihavainen, H., Viisanen, Y., Chubarova, N., Chalov, S., Filatov, N., Skorokhod,A., Elansky, N., Dyukarev, E., Esau', I., Hari, P., Kotlyakov, V., Kasimov, N., Bondur, V., Matvienko, G., Baklanov, A., Mareev, E., Troitskaya, Y., Ding, A., Guo, H., Zilitinkevich, S. and Kulmala, M. (2014) Pan-Eurasian Experiment (PEEX) - a research initiative meeting the grand challenges of the changing environment of the northern PanEurasian arctic-boreal areas, J. Geography Environment Sustainability, 2 (7), 13-48.

26. Lappalainen, H.K., Kerminen, V., Petäjä, T., Kurten, T., Baklanov, A., Shvidenko, A., Bäck, J. et al. (2016) Pan-Eurasian Experiment (PEEX): Towards holistic understanding of the feedbacks and interactions in the land - atmosphere - ocean-society continuum in the Northern Eurasian region, to be submitted ACP.

27. Lelieveld, J., Evans, J.S., Fnais, M., Giannadaki, D. and Pozzer, A. (2015) The contribution of outdoor air pollution sources to premature mortality on a global scale, Nature, 525, 367-371.

28. Nie, W., Ding, A., Wang, T., Kerminen, V.-M., George, C., Xue, L.,Wang, W., Zhang, Q, Petäjä, T., Qi, X., Gao, X., Wang, X, Yang, X., Fu, C. and Kulmala, M. (2014) Polluted dust promotes new particle formation and growth. Sci. Rep. 4, 6634, doi: 10.1038/srep06634.

29. Petäjä, T., Järvi, L., Kerminen, V.-M., Ding, A., Sun, J., Nie, W., Kujansuu, J., Virkkula, A., Yang, X., Fu, C., Zilitinkevich, S. and Kulmala, M. (2015) Enhanced air pollution via aerosolboundary layer feedback in China, Scientific Reports, (accepted).

30. Raes, F., Liao, H., Chen, W.-T. and Seinfeld, J.H. (2010), Atmospheric chemistry: climate feedbacks, J. Geophys. Res., 115. D12121, doi:10.1029/2009JD013300.

31. Schutgens, N.A. J. and Stier, P. (2014) A pathway analysis of global aerosol processes, Atmospheric Chemistry \& Physics, Vol. 14 Issue 21, p. 11657-11686. 
32. Shindell, D., Kuylenstierna, J.C.I., Vignati, E., van Dingenen, R., Amann, M., Klimont, Z., Anenberg, S.C., Muller, N., Janssens-Maenhout G., Raes, F., Schwartz, J., Faluvegi, G., Pozzoli, L., Kupiainen, K., Höglund-Isaksson L., Emberson, L., Streets, D., Ramanathan, V., Hicks, K.,. Kim Oanh N.Y., K., Milly, G., Williams, M., Demkine, V., and Fowler D. (2012) Simultaneously Mitigating Near-Term Climate Change and Improving Human Health and Food Security, Science, 335, 183-188.

33. Smith, L.C. (2010) The World in 2050: four forces shaping civilization's northern future, Brockman Inc.

34. Stocker, B.D., Roth, R., Joos, F., Spahn, R., Steinacher, M., Zaehle, S., Bouwman, L., Xu-Ri and Iain Colin Prentice I.C., (2013) Multiple greenhouse-gas feedbacks from the land biosphere under future climate change scenarios, Nature Climate Change, 3, 666-672, doi:10.1038/nclimate1864.

35. Unger, N., (2014) Human land-use-driven reduction of forest volatiles cools global climate, Nature Climate Change, 4.10, 907-910, DOl: 10.1038/nclimate2347.

36. Wanner, H., Beer, J. Bütikofer, T.J., Crowley, U. Cubasch, Flückiger, J., Goosse, H., Grosjean, M., Joos, F., Kaplan, J.O., Küttel, M., Müller, S.A., Prentice, I.C., Solomina, O., Stocker, T.F., Tarasov, P., Wagner, M.and Widmann, M., (2008) Mid- to Late Holocene climate change: An overview. Quat. Sci. Rev. 27, 1791-1828.

37. Westervelt, D.M., L.W. Horowitz, V. Naik, J.-C. Golaz, and D.L. and Mauzerall, (2015): Radiative forcing and climate response to projected 21 st century aerosol decreases, Atmos. Chem. Phys., 15, 12681-12703, doi:10.5194/acp-15-12681-2015.

38. WMO GAW (2014) The Global Atmosphere Watch Programme 25 Years of Global Coordinated Atmospheric Composition Observations and Analyses. W MO-No. 114 3, World Meteorological Organization, Geneva, 48 pp. ISBN 978-92-63-11143-2.

39. World Health Statistics 2014 (World Health Organization, Geneva, Switzerland, ISBN 97892-4-156471-7).

40. Xiao, S., Wang, M.Y., Yao, L., Kulmala, M., Zhou, B., Yang, X., Chen, J.M., Wang, D.F., Fu, Q.Y., Worsnop, W.R. and Wang, L. (2015) Strong atmospheric new particle formation in winter in urban Shanghai, China. Atmospheric Chemistry and Physics, 15 (4): 1769-1781.

41. Zhang, Y., Bocquet, M., Mallet, V., Seigneur, C. and Baklanov, A. (2012) Real-time air quality forecasting, part l: History, techniques, and current status, Atmos. Environ., 60, 656-676.

42. Zilitinkevich, S., Kulmala, M., Esau, I. and Baklanov, A (2015) Megacities - Refining Models to Client Environment, WMO Bulletin 64 (1), 20-22. 


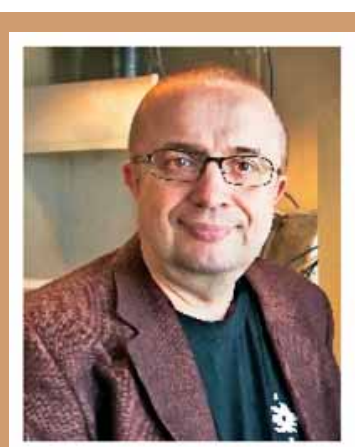

Academy Prof. Markku Kulmala directs the Division of Atmospheric Sciences at the Department of Physics, and has served as a professor at the University of Helsinki since 1996. Kulmala also acts as coordinator for the Centre of Excellence, appointed by the Academy of Finland first time in 2002; for Nordic Center of Excellence, appointed by Nordforsk ("Cryosphere-atmosphere interactions in a changing Arctic climate" (CRAICC)), which is the largest joint Nordic research and innovation initiative to date, aiming to strengthen research and innovation regarding climate change issues in the Nordic and high-latitude Regions; and international (Europe-Russia-China) Programme Pan-Eurasian Experiment (PEEX).Kulmala together with Prof. Pertti Hari is the primary inventor of the SMEAR concept. According to the ISI Web of Knowledge, M. Kulmala is in the first place in the Citation Rankings in Geosciences (since 1.5.2011). His $\mathrm{H}$-factor is 85. Prof. Kulmala has received several international awards such as the Smoluchovski Award (1997), the International Aerosol Fellow Award (2004), the Wilhelm Bjerkenes medals (2007), Fuchs Memorial Award (2010), Litke Medal (2015).

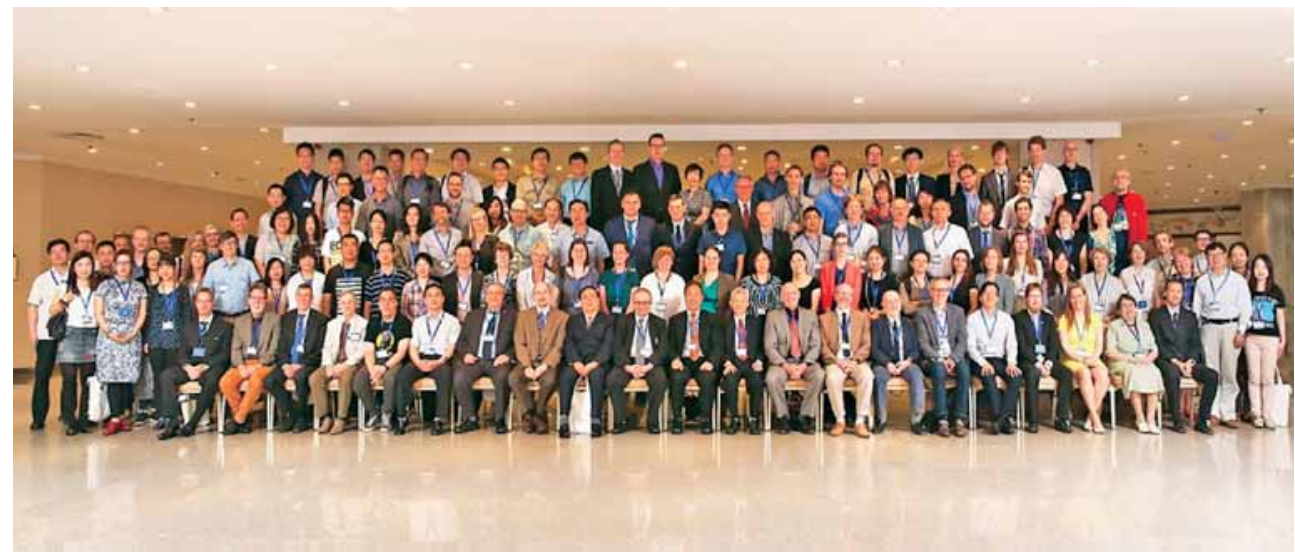

Pan-Eurasian Experiment (PEEX) is a bottom up initiative by several European, Russian, Chinese and North American research organizations and institutes. PEEX started in 2012 and set for the years 2013-2033 (-2100) as a long-term continuing activity. PEEX involves research communities representing 80 institutions from 20 different countries. 